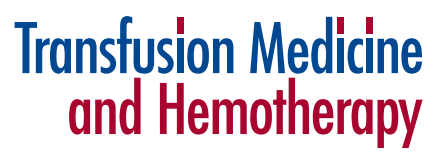

\title{
Clinical Results of Extracorporeal Photopheresis
}

\author{
Nina Worel Gerda Leitner \\ Department for Blood Group Serology and Transfusion Medicine, Medical University of Vienna, Austria
}

\author{
Keywords \\ Extracorporeal photopheresis - ECP . \\ Cutaneous T-cell lymphoma - CTCL . \\ Graft-versus-host disease $\cdot$ Solid organ rejection
}

\section{Summary}

Extracorporeal photopheresis (ECP) is a combination of leukapheresis and photodynamic therapy in which blood is treated with photoactivable drugs which are then activated with ultraviolet light and re-infused to the patient. It has been used successfully for more than 30 years in the treatment of erythrodermic cutaneous T-cell lymphoma (CTCL) and over 20 years for chronic graft-versus-host disease (GVHD). ECP has also shown promising results in the treatment of acute GVHD and other T-cellmediated diseases, including systemic sclerosis, treatment and prevention of solid organ rejection, and more recently Crohn's disease. The use of ECP may allow a significant reduction or even discontinuation of corticosteroids and/or other immunosuppressants, thus leading to reduced long-term morbidity and mortality and improved overall survival. ECP is a well-tolerated therapy. No significant side effects have been reported during the last 30 years. It has been shown that ECP is not associated with an increased incidence of infections, malignancies, or recurrence of underlying malignant disease, neither during short-term nor during long-term therapy.

\author{
Schlüsselwörter \\ Extrakorporale Photopherese - ECP . \\ Kutanes T-Zell-Lymphom · CTCL . \\ Graft-versus-Host Erkrankung · Organabstoßung
}

\section{Zusammenfassung}

Die extrakorporale Photopherese (ECP) ist eine Kombination aus Leukapherese und photodynamischer Therapie, bei der Blut mit photoaktiven Substanzen behandelt, mit ultraviolettem Licht bestrahlt und reinfundiert wird. Die ECP-Therapie wird seit 30 Jahren erfolgreich in der Behandlung von erythrodermen kutanen T-Zell-Lymphomen und seit 20 Jahren in der Behandlung von chronischer Graft-versus-Host-Erkrankung (GVHD) eingesetzt. Darüber hinaus konnten vielversprechende Ergebnisse in der Behandlung der akuten GVHD und anderer T-Zellmediierter Erkrankungen einschließlich Systemischer Sklerose, Behandlung und Prävention von Abstoßungsreaktion nach Transplantation solider Organe und kürzlich auch bei Therapie des Morbus Crohn gezeigt werden. Der Einsatz von ECP erlaubt eine signifikante Reduktion oder sogar das Absetzen von Steroiden und/ oder anderen immunsuppressiven Medikamenten, was zu einer Reduktion der Morbidität und Mortalität und zu einem verbesserten Gesamtüberleben führt. In den letzten 30 Jahren wurden keine signifikanten Nebenwirkungen der ECP berichtet. Es konnte gezeigt werden, dass die ECP weder bei kurzer, noch bei langer Anwendungsdauer mit einem erhöhten Risiko für das Auftreten von Infekten, Malignomen oder Rezidiv der zugrunde liegenden malignen Erkrankung vergesellschaftet ist.

\section{KARGER \\ Fax +497614520714 \\ Information@Karger.de}

www.karger.com (c) 2012 S. Karger GmbH, Freiburg

$1660-3796 / 12 / 0394-0254 \$ 38.00 / 0$

Accessible online at:

www.karger.com/tmh
Prof. Dr. med. Nina Worel

Department of Blood Group Serology and Transfusion Medicine

Medical University of Vienna

Währinger Gürtel 18-20, 1090 Wien, Austria

Tel. +431 40400 53-02, Fax -21

nina.worel@meduniwien.ac.at 


\section{Introduction}

Historically, vitiligo was the first treated disorder 5,000 years ago by Egypt physicians. After ingestion of the 'ami majus plant' patients were exposed to the sunshine.

Extracorporeal photochemotherapy (ECP) was introduced in 1981 in the USA by Richard L. Edelson and initially developed for the treatment of cutaneous T-cell lymphoma (CTCL) [1]. In 1988, ECP received approval by the American Food and Drug Agency (FDA) as the first sanctioned cellular immunotherapy for cancer. After the establishment of its high efficacy in CTCL, ECP has been investigated in several other T-cell-mediated diseases, including acute and chronic graftversus-host disease (GVHD), solid organ transplant rejection, systemic sclerosis, Crohn's disease (CD), and others. However, its mechanism of action still remains elusive. The treatment consists of two steps: a leukapheresis procedure collecting approximately $3-5 \%$ of circulating mononuclear cells and photoactivation by 8 -methoxypsoralen (8-MOP) and ultraviolet A light (UVA, 1-2 J/cm ${ }^{2}$ ). The treated cells are then re-infused to the patient. During ECP, photoactivated 8-MOP causes cross-linking of DNA within the nuclei of lymphocytes, leading to apoptosis of these cells. The key steps of ECP are apoptosis of mononuclear white blood cells (MNC, mainly lymphocytes) after treatment with photoactivated psoralen, phagocytosis of these apoptotic cells by antigen-presenting cells (APCs), a switch in APC activity in favor of antiinflammatory cytokines and away from proinflammatory cytokines, and production of antigen-specific T-regulatory cells (T-regs) [2]. Recent clinical and animal studies have demonstrated that infusion of apoptotic cells by ECP therapy induces antigenspecific T-regs, including CD4+ CD25+ FoxP3+ T cells and IL-10-producing T-regs type 1 . It has also been suggested that ECP therapy induces IL-10-producing regulatory B cells and regulatory CD8+ $\mathrm{T}$ cells [3].The frequency of CD4+ CD25+ FoxP3+ T-regs in the peripheral blood was shown to be increased after each cycle of ECP and also during the course of treatment [4]. A therapeutic dose of treated MNCs is still under discussion. No evidence of correlation between the number of lymphocytes collected and clinical efficacy has been found, although in one study a better clinical response and faster improvement in patients receiving higher doses of MNCs was reported [5]. Two concepts of photopheresis do currently exist: a single unit apheresis device (Therakos ${ }^{\mathrm{TM}}$ Uvar XTS $^{\circledR}$ or Therakos ${ }^{\mathrm{TM}}$ CellEx${ }^{\mathrm{TM}}$; Therakos Inc. Exton, PA, USA) and an 'offline' system requiring three separate processing steps (leukocyte collection, addition of psoralen plus UVA (PUVA) irradiation and re-infusion of treated cells) (fig. 1). In the beginning of ECP, 8-MOP was given orally $(0.5-0.6 \mathrm{mg} / \mathrm{kg})$ prior to apheresis procedure, causing in parts substantial side effects (e.g. nausea). Since 8-MOP now is administered just to the collected MNCs $(0.34 \mu \mathrm{g} / \mathrm{ml}$ collected cells), the total dose needed is typically only $0.25 \%$ of that used in the oral form [6]. Despite the patient has still to

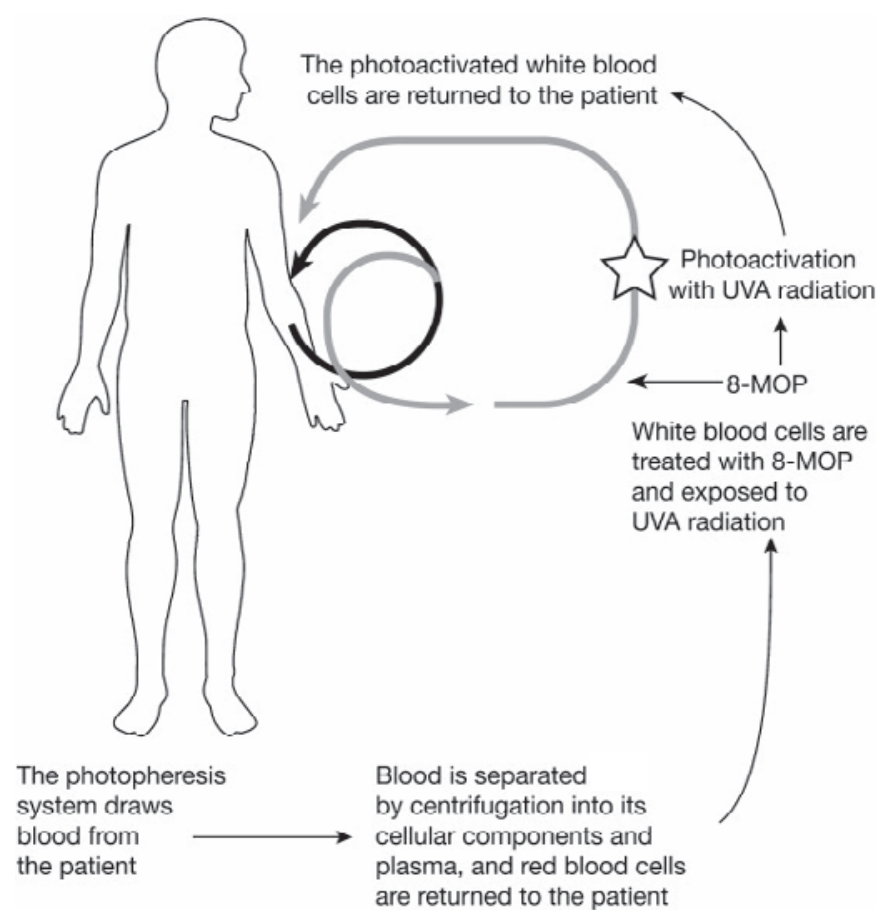

Fig. 1. During ECP whole blood is drawn from the patient and separated in plasma and different cell fractions. MNCs are collected, incubated with 8-MOP, photoactivated with UVA light and re-infused to the patient.

be aware, the post-treatment risk of photosensitization could be reduced by this approach.

ECP is a well-tolerated therapy. No significant side effects have been reported, except for the short-term effects of oral 8-MOP. A reduction in red cell and platelet counts has been observed. Unlike other immunosuppressive therapies, ECP has not been associated with an increased incidence of infections or malignancies, neither during short-term nor during long-term therapy.

\section{Extracorporeal Photochemotherapy in Dermatology}

\section{CTCLs}

Cutaneous lymphomas are disorders characterized by localization of malignant lymphocytes in the skin. The majority of these lymphomas (about two thirds) are of T-cell origin and the most common form of CTLCs is mycosis fungoides (MF; about $60 \%$ of CTCL cases). Systemic therapies are used only in progressive or advanced stage of disease [7]. In contrast, Sézary syndrome (SS) is less common and accounts for only $5 \%$ of CTCL cases. The prognosis is poor, with a median survival of less than 3 years [8].

In early stages, treatment usually consists of skin-directed therapies with topical agents including corticosteroids as well as phototherapy with PUVA, where patients take 8-MOP orally followed by skin exposure to UVA light [7]. However, PUVA is associated with short-term adverse events due to 
Table 1. ECP for the treatment of CTCL

\begin{tabular}{llllll}
\hline Author (reference) & Year & Patients & Overall response & CR & PR \\
\hline Edelson et al. [1] & 1987 & 37 & $73 \%(27 / 37)$ & $24 \%(9 / 37)$ & $35 \%(13 / 37)$ \\
Heald et al. [52] & 1989 & 22 & $86 \%(19 / 22)$ & $23 \%(5 / 22)$ & $45 \%(10 / 22)$ \\
Zic et al. [53] & 1992 & 20 & $55 \%(11 / 20)$ & $25 \%(5 / 20)$ & $30 \%(6 / 20)$ \\
Prinz et al. [54] & 1995 & 17 & $70 \%(12 / 17)$ & $0 \%(017)$ & $41 \%(7 / 17)$ \\
Gottlieb et al. [55] & 1996 & 28 & $71 \%(20 / 28)$ & $25 \%(7 / 28)$ & $46 \%(13 / 28)$ \\
Duvic et al. [56] & 1996 & 34 & $50 \%(17 / 34)$ & $18 \%(6 / 34)$ & $32 \%(11 / 34)$ \\
Vonderheid et al. [57] & 1998 & 36 & $33 \%(12 / 36)$ & $14 \%(5 / 36)$ & $19 \%(7 / 36)$ \\
Zouboulis et al. [58] & 1998 & 20 & $65 \%(13 / 20)$ & NK & NK \\
Jiang et al. [59] & 1999 & 25 & $80 \%(20 / 25)$ & $20 \%(5 / 25)$ & $60 \%(15 / 25)$ \\
Bisaccia et al. [60] & 2000 & 37 & $54 \%(20 / 37)$ & $14 \%(5 / 37)$ & $41 \%(15 / 37)$ \\
Crovetti et al. [61] & 2000 & 30 & $73 \%(22 / 30)$ & $33 \%(1030)$ & $40 \%(12 / 30)$ \\
Wollina et al. [62] & 2000 & 20 & $65 \%(13 / 20)$ & $50 \%(1020)$ & $15 \%(3 / 20)$ \\
Bouwhuis et al. [63] & 2002 & 55 & $80 \%(4455)$ & $62 \%(34 / 55)$ & $18 \%(1055)$ \\
Knobler et al. [64] & 2002 & 20 & $50 \%(10 / 20)$ & $15 \%(3 / 20)$ & $35 \%(7 / 20)$ \\
Suchin et al. [65] & 2002 & 47 & $79 \%(37 / 47)$ & $26 \%(12 / 47)$ & $53 \%(25 / 47)$ \\
Quaglino et al. [66] & 2004 & 19 & $63 \%(12 / 19)$ & NK & NK \\
Richardson et al. [67] & 2006 & 28 & $89 \%(25 / 28)$ & $29 \%(8 / 28)$ & $61 \%(17 / 28)$ \\
\hline
\end{tabular}

$\mathrm{CR}=$ Complete response; $\mathrm{PR}=$ partial response $(>50 \%$ improvement in skin scores $)$;

$\mathrm{NK}=$ not known.

psoralen intake (e.g. nausea, vomiting) and long-term complications such as photosensitivity and the potential for the development of skin cancer. Since the publication of the first multicenter trial of ECP by Edelson in 1987 reporting responses in $27 / 37(73 \%)$ of patients with advanced refractory CTCL, data on $>1,000$ patients with CTCL treated with ECP have been reported from worldwide centers [9]. The European Organization for Research and Treatment of Cancer (EORTC) recently published European consensus recommendations for the treatment of MF/SS based on available evidence and best practices from each national group [7]. ECP is recommended as a first-line therapy for both erythrodermic MF and SS. The standard schedule for ECP in the treatment of CTCL consists of procedures performed on 2 consecutive days every $2-4$ weeks, which is generally continued for up to 6 months to assess response. Maintenance therapy may be tailored according to disease response and severity. It was also noted that the response rate to ECP may be increased with the addition of immunomodulatory therapy such as IFN- $\alpha$ [7]. Response rates to ECP have been shown to vary widely between different study groups, from 43 to $100 \%$ [10]. A summary of the largest studies publishing response rates using ECP for the treatment of CTCL is provided in table 1 . The differences in response rates between centers may relate to different patient selection for treatment with ECP such as the presence of a peripheral T-cell clone, stage of disease, prior treatment, ECP protocol, duration of ECP, and definition of response [10].

One major consequence of ECP in CTCL is the induction of apoptosis resulting from the fact that 8-MOP binds covalently to DNA in the separated leukocytes, leading to cell cycle arrest and apoptosis after UVA irradiation. The phago- cytosis of apoptotic leukocytes by antigen-presenting cells and impaired function of other dying cells induce several changes in the immune response through many different actors such as dendritic cells, regulatory cells and cytokine pattern modifications.

\section{Systemic Sclerosis}

Systemic sclerosis (SSc) is an autoimmune connective tissue disorder of unknown etiology characterized by abnormal excessive deposition of collagen and obliterative vasculopathy in the skin and visceral organs, such as the kidneys, heart, lungs, and gastrointestinal tract. Patients with severe, progressive SSc have a relatively poor prognosis with a 10 -year survival rate of about $20 \%$ [11].

In a randomized, single-blind, controlled trial including 79 patients, ECP was shown to induce a significant improvement in skin severity scores and mean percentage of skin involvement when compared with a control group of patients only receiving D-penicillamine treatment. After 6 months of treatment, a statistically significant reduction in skin severity scores was observed in $68 \%$ of patients receiving ECP as compared with $32 \%$ of patients on a regimen of D-penicillamine [12].

Subsequently, a randomized, double-blind, placebo-controlled trial conducted at 16 investigational sites in the USA, Canada, and Europe was initiated by Knobler et al. [13]. Patients were randomized at baseline to receive either active or sham ECP according to a secure computer-generated randomization schedule. Treatment was performed on 2 consecutive days every 4 weeks for 12 months. Severity of skin (skin scores assessed in 22 body regions) and joint involvement (60 joints examined for contractures) were assessed on a monthly basis. A statistically significant improvement in skin scores as 
compared with baseline was observed at 6 months and 12 months among patients who received active ECP, but not among patients who received sham ECP. Comparison of skin scores between the two study arms did not achieve statistical significance because of the small sample size of the study arms. Joint involvement was also significantly improved after 6 months and 12 months of active ECP when compared with baseline [13]. Based on the available literature, especially patients with early stage of disease and significant skin involvement seem to respond best to ECP. However, only long-term treatment leads to continuous improvement in SSc patients.

\section{Extracorporeal Photochemotherapy in Transplantation}

\section{Acute GVHD}

Acute GVHD is a frequent complication of allogeneic hematopoietic stem cell transplantation (HCT) that occurs in approximately $60 \%$ of HLA-identical sibling transplants [14] and up to $80 \%$ of matched unrelated donor transplants [15] and contributes substantially to post-transplantation morbidity and mortality. HLA disparity, patient and donor age and gender, dose and source of hematopoietic stem cells, intensity of conditioning regimen and GVHD prophylaxis can influence development of GVHD [14, 16, 17]. After myeloablative conditioning regimens, acute GVHD occurs within 2-4 weeks after HCT, whereas after reduced-intensity conditioning the onset of acute GVHD may be delayed until 2-3 months after HCT. Recently, the National Institutes of Health (NIH) Consensus Development Project distinguished classic acute GVHD presenting within 100 days of HCT with acute GVHD features from persistent, recurrent, or late-onset acute GVHD occurring beyond 100 days of HCT or donor lymphocyte infusion (DLI) [18].

The major target organs affected by acute GVHD are skin, liver, and gastrointestinal tract. Skin manifestations consist of maculopapular rash, erythrodermia, bullae formation, and epidermal separation similar to toxic epidermal necrolysis. Liver GVHD manifests with hyperbilirubinemia as well as increased alkaline phosphatase and transaminase levels. Gastrointestinal involvement is characterized by diarrhea and in some patients by persistent nausea. Criteria for grading acute GVHD were published in 1974 by Glucksberg and colleagues [19].

The established first-line therapy for treatment of acute GVHD consists of corticosteroids since more than 25 years [20]. However, only $24 \%$ of patients after unrelated HCT and about $40 \%$ of patients after related HCT respond to this approach $[20,21]$. Non-responding patients require additional immunosuppressive therapy (e.g. poly- or monoclonal antibodies, immunotoxins, other immunosuppressive interventions) are at high risk for additional morbidity and mortality due to life-threatening infections, including invasive fungal, bacterial and viral infections or organ failure.

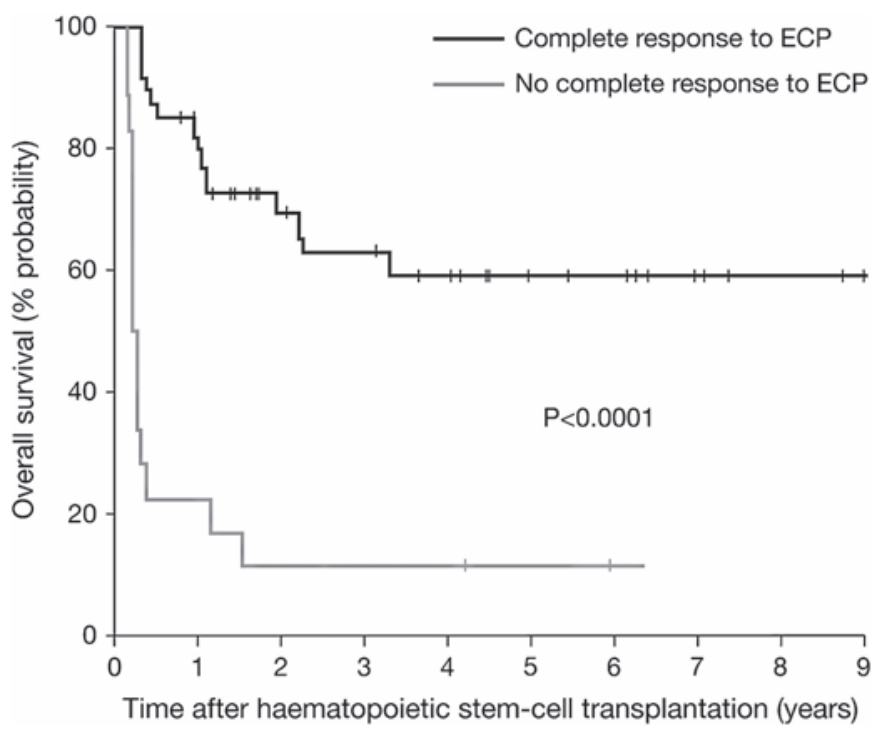

Fig. 2. Kaplan-Meier probability of overall survival among patients with steroid-refractory and -dependent acute GVHD was significantly higher among those showing complete response (CR) to ECP (black line) compared with those with no CR to ECP (grey line).

This figure was published in Greinix, et al: The effect of intensified extracorporeal photochemotherapy on long-term survival in patients with severe acute graft-versus-host disease. Haematologica 2006;91:405-408, Copyright (C) 2006 Ferrata Storti Foundation.

After promising results of early studies with ECP in patients with steroid-refractory GVHD [22, 23], a pilot study in 21 steroid-refractory patients was initiated, showing an overall complete response rate of $60 \%$ after 3 months of ECP [24]. Subsequently, a prospective phase II study was performed by Greinix et al. [25] with the so far largest treated cohort, including 37 steroid-refractory and 22 steroid-dependent GVHD patients. Patients underwent ECP on 2 days a week (= one cycle) in weekly intervals until maximal response was achieved. Then, ECP was stopped without maintenance therapy. A complete resolution of acute GVHD was achieved in $82 \%$ of patients with skin, in $61 \%$ with liver, and in $61 \%$ with gut transplants after a median of 4 cycles of ECP, during a median of 1.3 months of therapy. Complete response rates were higher for patients with grade II and III disease (86\% and $55 \%$, respectively) than for grade IV disease $(30 \%)$. Using an intensified ECP schedule with two treatments on a weekly basis, response rates in grade IV disease and gut involvement could be improved significantly compared to the pilot study [24]. ECP allowed accelerated tapering of corticosteroids and their discontinuation in responders after a median of 55 days, which had a positive effect on transplantation-related mortality. The probability of overall survival projected at 4 years was significantly higher for patients who achieved a complete response to ECP (59\% vs. $11 \%)$, compared with those who did not (fig. 2). These long-term results demonstrated that the effects of ECP in patients with acute GVHD were durable and improved overall survival. The most impor- 
Table 2. ECP in patients with steroidrefractory acute GVHD

\begin{tabular}{lcccccc}
\hline Author (reference) & Year & Patients & CR/PR skin, \% & CR/PR liver, \% & CR/PR gut, \% & Overall survival, \% \\
\hline Greinix et al. [23] & 1998 & 6 & 100 & 100 & & 100 \\
Greinix et al. [24] & 2000 & 21 & 81 & 67 & 0 & 57 \\
Salvaneschi et al. [68] & 2001 & 9 & 89 & 20 & 60 & 67 \\
Dall'Amico et al. [69] & 2002 & 14 & 79 & 57 & 70 & 57 \\
Messina et al. [34] & 2003 & 33 & 82 & 60 & 75 & 69 \\
Garban et al. [70] & 2005 & 12 & 67 & 0 & 40 & 42 \\
Greinix et al. [25] & 2006 & 59 & 93 & 65 & 74 & 59 \\
Kanold et al. [71] & 2007 & 12 & 100 & 67 & 83 & 75 \\
Perfetti et al. [72] & 2008 & 23 & 66 & 27 & 40 & 48 \\
Calore et al. [73] & 2008 & 15 & 92 & 100 & 71 & 85 \\
Perotti et al. [74] & 2010 & 50 & 83 & 67 & 73 & 64 \\
\hline
\end{tabular}

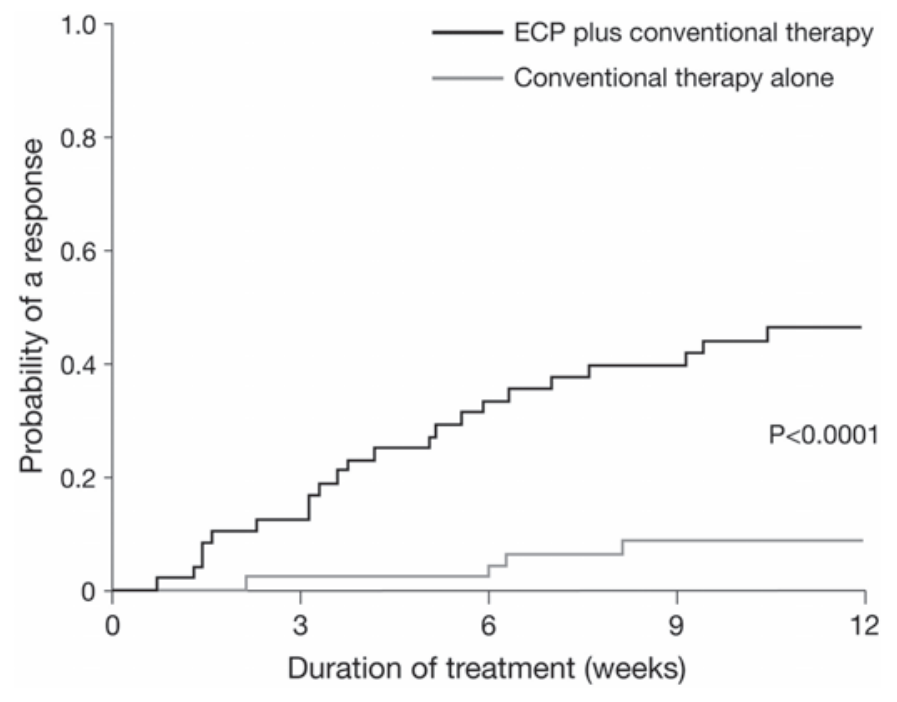

Fig. 3. Cumulative incidence of complete or partial response of skin was higher among patients with steroid-refractory/-dependent/-intolerant chronic GVHD treated with ECP than in the control group.

This figure was originally published in Flowers et al: A multicenter prospective phase 2 randomized study of extracorporeal photopheresis for treatment of chronic graft-versus-host disease. Blood 2008;112:2593-2594, Copyright (C) 2008 The American Society of Hematology.

tant findings in ECP treatment of patients with acute GVHD are that ECP is steroid-sparing, does not impair the graft-versus-leukemia effect, and does not increase the risk for opportunistic infections. Since neither increased rates of infections nor recurrence of underlying malignant disease have been observed during ECP [24], this promising treatment is unlikely to induce a generalized immunosuppression. Table 2 summarizes the main published results on the use of ECP in patients with acute GVHD who failed steroid first-line therapy.

\section{Chronic GVHD}

Chronic GVHD affects $30-80 \%$ of HCT recipients depending on patient age, donor type, stem cell source, graft manipulation, and the use of DLI [26-28]. It is a multiorgan autoim- mune-like syndrome similar to other immunologic disorders such as scleroderma, Sjögren syndrome, primary biliary cirrhosis, bronchiolitis obliterans, immune cytopenias, and chronic immunodeficiency. Severe chronic GVHD has a major influence on late morbidity and mortality after HCT; if untreated, fewer than $20 \%$ of patients survive without disability at 4 years after HCT [29, 30]. Lower survival rates, higher non-relapse mortality and longer duration of systemic immunosuppressive therapy are reported in patients with high-risk features of chronic GVHD like platelet counts $<100 \times 10^{9} / 1$ or progressive onset of chronic GVHD [31].

The classification of chronic GVHD as to be 'limited' or 'extensive' was based on results of a small retrospective study performed in 1980 [32]. The NIH Consensus Development Project on Criteria for Clinical Trials in chronic GVHD developed recently standardized criteria for diagnosis of chronic GVHD and a new scoring system for describing the extent and severity of chronic GVHD [18].

Again, corticosteroids represent a major treatment component. However, therapy of chronic GVHD should begin as soon as possible after initial diagnosis to improve the longterm outcome of patients. Overall survival at 3 years is reported to be $76 \%$ if corticosteroids are started early compared to only $23 \%$ if started late in the course of disease [30, 33].

During the last years a remarkable number of patients has been treated with ECP for steroid-refractory chronic GVHD, high response rates have been reported in cutaneous and visceral manifestations [23, 34]. Patients with severe sclerodermatous chronic GVHD had a clear benefit from longer treatment duration [23, 25]. Several retrospective studies demonstrated the efficacy of ECP for patients with chronic GVHD, but no association between treatment intensity (number of ECP procedures per month) and clinical response could be found [25]. Responses to ECP appear to be more frequent in patients treated earlier (less than 9 months) after diagnosis of chronic GVHD, a steroid-sparing effect could be demonstrated, and in the majority of responders other immunosuppressants could be discontinued [34, 35]. Messina and col- 
Table 3. ECP in patients with steroid-refractory chronic GVHD

\begin{tabular}{lllll}
\hline Author (reference) & Year & Patients & ORR (\%) & Survival \\
\hline Greinix et al. [23] & 1998 & 15 & 8 CR, 6 PR (93) & $14 / 15(93 \%)$ at 15 mo \\
Smith et al. [75] & 1998 & 18 & 3 CR, 3 PR (33) & $7 / 18(39 \%)$ at 2 y \\
Salvaneschi et al. [68] & 2001 & 14 & 4 CR, 5 PR (64) & $11 / 14(79 \%)$ at 3 y \\
Messina et al. [34] & 2003 & 44 & 15 CR, 10 PR (68) & $34 / 44(77 \%)$ \\
Seaton et al. [76] & 2003 & 28 & 10 PR (36) & $24 / 28(86 \%)$ \\
Apisarnthanarax et al. [77] & 2003 & 32 & 7 CR, 11 PR (56) & $19 / 32(59 \%)$ \\
Foss et al. [78] & 2005 & 25 & 16 PR (64) & $15 / 25(60 \%)$ \\
Rubegni et al. [79] & 2005 & 32 & 9 CR, 13 PR (69) & \\
Couriel et al. [35] & 2006 & 71 & 14 CR, 29 PR (61) & $13 / 71(18 \%)$ at 5 y \\
Greinix et al. [25] & 2006 & 47 & 23 CR, 16 PR (83) & $42 / 47(89 \%)$ \\
Perseghin et al. [80] & 2007 & 25 & 11 CR, 9 PR (80) & $19 / 25(76 \%)$ at 2 y \\
\hline ORR = Overall response rate; CR complete response; PR = partial response; mo = months; \\
y = years.
\end{tabular}

leagues [34] observed a significantly higher 5-year overall survival rate (96\% vs. $58 \%$ ) in patients responding to ECP compared to non-responders. Recently, results of a multicenter, prospective, randomized, phase II study in 95 patients witch steroid-refractory, steroid-dependent, or steroid-intolerant chronic GVHD were published. Patients were randomized either to conventional treatment with steroids plus calcineurin inhibitors or to conventional treatment plus ECP for 24 weeks [36]. Patients were treated with ECP 3 times during week 1, then twice weekly during weeks $2-12$, and responding patients could continue 2 ECP treatments every 4 weeks until week 24 . Numerically greater improvements in total skin score (TSS) were observed with ECP plus conventional treatment than with conventional treatment alone although the difference was not statistically significant. However, ECP lead to significantly higher complete response and partial response $(40 \%$ compared to $10 \%$ ), and the proportion of patients who had at least a $50 \%$ reduction in steroid dose and at least a $25 \%$ decrease from baseline in the TSS was $8.3 \%$ at week 12 compared to $0 \%$ with conventional therapy alone.

Table 3 summarizes the main published results on the use of ECP in patients with chronic GVHD.

\section{Solid Organ Transplant Rejection}

Early, small pilot studies in patients with cardiac transplant rejection indicated that ECP in addition to conventional immunosuppressive treatment could reduce or reverse rejection and reduce the incidence of rejection episodes [37, 38]. Subsequently, larger studies followed to investigate the prophylactic use of ECP in this setting [39]. A phase II study analyzed the impact of ECP given or not given in addition to conventional immunosuppression within $30 \mathrm{~h}$ of primary cardiac transplantation in 61 patients. The ECP group had a significant reduction of acute rejection episodes compared to standard therapy alone $(61 \%$ vs. $81 \%)$ [40].

In lung transplant recipients the development of bronchiolitis obliterans syndrome (BOS) - a form of chronic allograft rejection - remains a major complication [41]. A retrospective analysis of 14 patients with BOS demonstrated the benefit of $\mathrm{ECP}$ in reversing acute rejection and treating low-grade BOS [42]. Overall, data of approximately 50 patients receiving ECP after lung transplantation are available in the literature. ECP seems to be very effective to treat acute rejection: ECP treatment was successful in14 of 16 published cases. With regard to BOS, 12 of 45 patients improved and 16 of 45 remained stable. These patients, however, were already resistant to other therapies and had advanced disease.

Case reports and small studies have also demonstrated the benefit of ECP in the management of liver and renal transplant rejection or as rejection prophylaxis. Urbani et al. [43] showed reversal of graft rejection after hepatic transplantation in 5 patients; in 3 of them immunosuppressants could be reduced. Additional studies have been performed using ECP for prophylaxis of allograft rejection in case of delayed introduction of calcineurin inhibitors (CNI) among high-risk liver transplant recipients to avoid CNI toxicity. Another approach is the use of ECP for prevention of acute cellular rejection among ABO-incompatible liver transplant recipients, where none of the reported 11 patients treated with ECP developed a cell-mediated rejection [44]. In patients with renal allograft rejection, small studies could show that ECP was able to reverse rejection in patients who were refractory to conventional treatment and led to improved or stable graft function [45-47]. However, controlled studies with larger patient numbers are needed to confirm these findings in liver and renal transplant.

\section{$E C P$ in $C D$}

$\mathrm{CD}$ is a progressive, relapsing, T-cell-mediated inflammatory disorder, treated with systemic steroids and salicylate or, in more advanced stages, in combination with immunomodulators and/or TNF- $\alpha$ antagonists. Small preliminary studies evaluating the impact of ECP showed that a discontinuation or marked reduction of steroid dose could be achieved in treated patients. However, long duration of refractory CD leads to less well responses, suggesting an early use in patients with steroid- 
Table 4. Clinical applications of ECP therapy

\begin{tabular}{ll}
\hline Disease & ASFA category \\
\hline CTCL (including SS) & \\
$\quad$ Erythrodermic & I \\
$\quad$ Non-erythrodermic & III \\
GVHD & \\
$\quad$ Skin (acute and chronic) & II \\
$\quad$ Non-skin (acute and chronic) & III \\
Heart transplant & \\
$\quad$ Prophylaxis & I \\
$\quad$ Rejection & II \\
Lung transplant rejection & II \\
Liver transplant rejection & not rated \\
Kidney transplant rejection & not rated \\
Scleroderma (progressive SSc) & IV \\
Pemphigus vulgaris & III \\
CD & not rated \\
\hline ASFA = American Society for Apheresis & \\
\hline
\end{tabular}

dependent disease $[48,49]$. In a recent multicenter study including 28 patients with moderate to severe CD refractory to immunomodulators and/or TNF- $\alpha$ antagonists, ECP treatment achieved a marked reduction in CD activity: $50 \%$ of patients responded and $25 \%$ were in remission [50].

\section{Conclusion}

According to the literature published thus far, ECP is an established first-line therapy in CTCL. In other severe and difficult-to-treat circumstances, such as acute and chronic GVHD, SSc or allograft rejection, ECP has shown improved efficacy. Guidelines on the use of therapeutic apheresis in clinical practice have been established from the Apheresis Applications Committee of the American Society for Apheresis (ASFA guidelines) and are shown in table 4 [51]. As ECP treatment allows to reduce the dosage of corticosteroids and other immunosuppressive drugs, reduced long-term morbidity and mortality in responding patients has been reported.

The data collected during the last 25 years of the use of ECP demonstrated that the procedure is tolerated well, with no clinically significant side effects.

\section{Disclosure Statement}

The authors declare that they have no competing interests.

\section{References}

1 Edelson R, Berger C, Gasparro F, Jegasothy B, Heald P, Wintroub B, Vonderheid E, Knobler R, Wolff K, Plewig G, et al: Treatment of cutaneous T-cell lymphoma by extracorporeal photochemotherapy. Preliminary results. N Engl J Med 1987; 316:297-303.

2 Ward DM: Extracorporeal photopheresis: how, when, and why. J Clin Apher 2011;26:276-285.

3 Xia CQ, Campbell KA, Clare-Salzler MJ: Extracorporeal photopheresis-induced immune tolerance: a focus on modulation of antigen-presenting cells and induction of regulatory $\mathrm{T}$ cells by apoptotic cells. Curr Opin Organ Transplant 2009;14:338-343.

$\checkmark$ Schmitt S, Johnson TS, Karakhanova S, Naher H, Mahnke K, Enk AH: Extracorporeal photophoresis augments function of CD4+CD25+FoxP3+ regulatory $\mathrm{T}$ cells by triggering adenosine production. Transplantation 2009;88:411-416.

$\checkmark 5$ Perseghin P, Dassi M, Balduzzi A, Rovelli A, Bonanomi S, Uderzo C: Mononuclear cell collection in patients undergoing extra-corporeal photo-chemotherapy for acute and chronic graft-vs.-host-disease (GvHD): comparison between COBE Spectra version 4.7 and 6.0 (AutoPBSC). J Clin Apher 2002; 17:65-71.

6 Knobler RM, Trautinger F, Graninger W, Macheiner W, Gruenwald C, Neumann R, Ramer W: Parenteral administration of 8-methoxypsoralen in photopheresis. J Am Acad Dermatol 1993;28: 580-584.

7 Trautinger F, Knobler R, Willemze R, Peris K, Stadler R, Laroche L, D'Incan M, Ranki A, Pimpinelli N, Ortiz-Romero P, Dummer R, Estrach T, Whittaker S: EORTC consensus recommendations for the treatment of mycosis fungoides/Sezary syndrome. Eur J Cancer 2006;42:1014-1030.
8 Scarisbrick JJ: Staging and management of cutaneous T-cell lymphoma. Clin Exp Dermatol 2006;31: 181-186.

9 Scarisbrick JJ, Taylor P, Holtick U, Makar Y, Douglas K, Berlin G, Juvonen E, Marshall S: U.K. consensus statement on the use of extracorporeal photopheresis for treatment of cutaneous T-cell lymphoma and chronic graft-versus-host disease. Br J Dermatol 2008;158:659-678.

10 McKenna KE, Whittaker S, Rhodes LE, Taylor P, Lloyd J, Ibbotson S, Russell-Jones R: Evidencebased practice of photopheresis 1987-2001: a report of a workshop of the British Photodermatology Group and the U.K. Skin Lymphoma Group. Br J Dermatol 2006;154:7-20.

11 Perez MI, Kohn SR: Systemic sclerosis. J Am Acad Dermatol 1993;28:525-547.

12 Rook AH, Freundlich B, Jegasothy BV, Perez MI, Barr WG, Jimenez SA, Rietschel RL, Wintroub B, Kahaleh MB, Varga J, et al: Treatment of systemic sclerosis with extracorporeal photochemotherapy. Results of a multicenter trial. Arch Dermatol 1992; 128:337-346

13 Knobler RM, French LE, Kim Y, Bisaccia E, Graninger W, Nahavandi H, Strobl FJ, Keystone E, Mehlmauer M, Rook AH, Braverman I: A randomized, double-blind, placebo-controlled trial of photopheresis in systemic sclerosis. J Am Acad Dermatol 2006;54: 793-799.

14 Weisdorf D, Hakke R, Blazar B, Miller W, McGlave P, Ramsay N, Kersey J, Filipovich A: Risk factors for acute graft-versus-host disease in histocompatible donor bone marrow transplantation. Transplantation 1991;51:1197-1203.
15 Beatty PG, Hansen JA, Longton GM, Thomas ED, Sanders JE, Martin PJ, Bearman SI, Anasetti C, Petersdorf EW, Mickelson EM, et al: Marrow transplantation from HLA-matched unrelated donors for treatment of hematologic malignancies. Transplantation 1991:51:443-447.

16 Couriel D, Caldera H, Champlin R, Komanduri K: Acute graft-versus-host disease: pathophysiology, clinical manifestations, and management. Cancer 2004;101:1936-1946.

17 Eapen M, Rocha V, Sanz G, Scaradavou A, Zhang MJ, Arcese W, Sirvent A, Champlin RE, Chao N, Gee AP, Isola L, Laughlin MJ, Marks DI, Nabhan S, Ruggeri A, Soiffer R, Horowitz MM, Gluckman E, Wagner JE: Effect of graft source on unrelated donor haemopoietic stem-cell transplantation in adults with acute leukaemia: a retrospective analysis. Lancet Oncol 2010;11: 653-660.

18 Filipovich AH, Weisdorf D, Pavletic S, Socie G, Wingard JR, Lee SJ, Martin P, Chien J, Przepiorka D, Couriel D, Cowen EW, Dinndorf P, Farrell A, Hartzman R, Henslee-Downey J, Jacobsohn D, McDonald G, Mittleman B, Rizzo JD, Robinson M, Schubert M, Schultz K, Shulman H, Turner M, Vogelsang G, Flowers ME: National Institutes of Health consensus development project on criteria for clinical trials in chronic graft-versus-host disease: I. Diagnosis and staging working group report. Biol Blood Marrow Transplant 2005;11:945-956.

19 Glucksberg H, Storb R, Fefer A, Buckner CD, Neiman PE, Clift RA, Lerner KG, Thomas ED: Clinical manifestations of graft-versus-host disease in human recipients of marrow from HL-A-matched sibling donors. Transplantation 1974;18:295-304. 
20 Martin PJ, Schoch G, Fisher L, Byers V, Anasetti C, Appelbaum FR, Beatty PG, Doney K, McDonald GB, Sanders JE, et al: A retrospective analysis of therapy for acute graft-versus-host disease: initial treatment. Blood 1990;76:1464-1472

21 Roy J, McGlave PB, Filipovich AH, Miller WJ, Blazar BR, Ramsay NK, Kersey JH, Weisdorf DJ: Acute graft-versus-host disease following unrelated donor marrow transplantation: failure of conventional therapy. Bone Marrow Transplant 1992;10: $77-82$.

-22 Dall'Amico R, Zacchello G: Treatment of graftversus-host disease with photopheresis. Transplantation 1998;65:1283-1284.

23 Greinix HT, Volc-Platzer B, Rabitsch W, Gmeinhart B, Guevara-Pineda C, Kalhs P, Krutmann J, Honigsmann H, Ciovica M, Knobler RM: Successful use of extracorporeal photochemotherapy in the treatment of severe acute and chronic graftversus-host disease. Blood 1998;92:3098-3104.

24 Greinix HT, Volc-Platzer B, Kalhs P, Fischer G, Rosenmayr A, Keil F, Honigsmann H, Knobler RM: Extracorporeal photochemotherapy in the treatment of severe steroid-refractory acute graft-versushost disease: a pilot study. Blood 2000;96:2426-2431.

-25 Greinix HT, Knobler RM, Worel N, Schneider B, Schneeberger A, Hoecker P, Mitterbauer M, Rabitsch W, Schulenburg A, Kalhs P: The effect of intensified extracorporeal photochemotherapy on longterm survival in patients with severe acute graft-versus-host disease. Haematologica 2006;91:405-408.

-26 Lee SJ, Vogelsang G, Gilman A, Weisdorf DJ, Pavletic S, Antin JH, Horowitz MM, Akpek G, Flowers ME, Couriel D, Martin PJ: A survey of diagnosis, management, and grading of chronic GVHD. Biol Blood Marrow Transplant 2002;8:32-39.

27 Schmitz N, Eapen M, Horowitz MM, Zhang MJ, Klein JP, Rizzo JD, Loberiza FR, Gratwohl A, Champlin RE: Long-term outcome of patients given transplants of mobilized blood or bone marrow: a report from the International Bone Marrow Transplant Registry and the European Group for Blood and Marrow Transplantation. Blood 2006; 108:4288-4290.

-28 Abou-Mourad YR, Lau BC, Barnett MJ, Forrest DL, Hogge DE, Nantel SH, Nevill TJ, Shepherd JD, Smith CA, Song KW, Sutherland HJ, Toze CL, Lavoie JC: Long-term outcome after allo-SCT: close follow-up on a large cohort treated with myeloablative regimens. Bone Marrow Transplant 2010;45:295-302.

29 Socie G, Stone JV, Wingard JR, Weisdorf D, Henslee-Downey PJ, Bredeson C, Cahn JY, Passweg JR, Rowlings PA, Schouten HC, Kolb HJ, Klein JP: Long-term survival and late deaths after allogeneic bone marrow transplantation. Late Effects Working Committee of the International Bone Marrow Transplant Registry. N Engl J Med 1999;341:14-21.

-30 Sullivan KM, Shulman HM, Storb R, Weiden PL, Witherspoon RP, McDonald GB, Schubert MM, Atkinson K, Thomas ED: Chronic graft-versushost disease in 52 patients: adverse natural course and successful treatment with combination immunosuppression. Blood 1981;57:267-276.

-31 Flowers ME, Parker PM, Johnston LJ, Matos AV, Storer B, Bensinger WI, Storb R, Appelbaum FR, Forman SJ, Blume KG, Martin PJ: Comparison of chronic graft-versus-host disease after transplantation of peripheral blood stem cells versus bone marrow in allogeneic recipients: long-term followup of a randomized trial. Blood 2002;100:415-419.
32 Shulman HM, Sullivan KM, Weiden PL, McDonald GB, Striker GE, Sale GE, Hackman R, Tsoi MS, Storb R, Thomas ED: Chronic graft-versushost syndrome in man. A long-term clinicopathologic study of 20 Seattle patients. Am J Med 1980;69:204-217.

33 Sullivan KM, Witherspoon RP, Storb R, Deeg HJ, Dahlberg S, Sanders JE, Appelbaum FR, Doney KC, Weiden P, Anasetti C, et al: Alternating-day cyclosporine and prednisone for treatment of highrisk chronic graft-v-host disease. Blood 1988;72: 555-561.

34 Messina C, Locatelli F, Lanino E, Uderzo C, Zacchello G, Cesaro S, Pillon M, Perotti C, Del Fante C, Faraci M, Rivabella L, Calore E, De Stefano P, Zecca M, Giorgiani G, Brugiolo A, Balduzzi A, Dini G, Zanesco L, Dall'Amico R: Extracorporeal photochemotherapy for paediatric patients with graftversus-host disease after haematopoietic stem cell transplantation. Br J Haematol 2003;122:118-127.

35 Couriel DR, Hosing C, Saliba R, Shpall EJ, Anderlini P, Rhodes B, Smith V, Khouri I, Giralt S, de Lima M, Hsu Y, Ghosh S, Neumann J, Andersson B, Qazilbash M, Hymes S, Kim S, Champlin R, Donato $\mathrm{M}$ : Extracorporeal photochemotherapy for the treatment of steroid-resistant chronic GVHD. Blood 2006;107:3074-3080.

36 Flowers ME, Apperley JF, van Besien K, Elmaagacli A, Grigg A, Reddy V, Bacigalupo A, Kolb HJ, Bouzas L, Michallet M, Prince HM, Knobler R, Parenti D, Gallo J, Greinix HT: A multicenter prospective phase 2 randomized study of extracorporeal photopheresis for treatment of chronic graftversus-host disease. Blood 2008;112:2667-2674.

37 Costanzo-Nordin MR, Hubbell EA, O'Sullivan EJ, Johnson MR, Mullen GM, Heroux AL, Kao WG, McManus BM, Pifarre R, Robinson JA: Successful treatment of heart transplant rejection with photopheresis. Transplantation 1992;53:808-815.

38 Dall'Amico R, Montini G, Murer L, Andreetta B, Zacchello G, Gambino A, Feltrin G, Caforio A, Tursi V, Livi U: Extracorporeal photochemotherapy after cardiac transplantation: a new therapeutic approach to allograft rejection. Int J Artif Organs 2000;23:49-54.

39 Barr ML, Baker CJ, Schenkel FA, McLaughlin SN, Stouch BC, Starnes VA, Rose EA: Prophylactic photopheresis and chronic rejection: effects on graft intimal hyperplasia in cardiac transplantation. Clin Transplant 2000;14:162-166.

40 Barr ML, Meiser BM, Eisen HJ, Roberts RF, Livi U, Dall'Amico R, Dorent R, Rogers JG, Radovancevic B, Taylor DO, Jeevanandam V, Marboe CC: Photopheresis for the prevention of rejection in cardiac transplantation. Photopheresis Transplantation Study Group. N Engl J Med 1998;339:1744-1751.

41 Estenne M, Maurer JR, Boehler A, Egan JJ, Frost A, Hertz M, Mallory GB, Snell GI, Yousem S: Bronchiolitis obliterans syndrome 2001: an update of the diagnostic criteria. J Heart Lung Transplant 2002;21:297-310.

42 Villanueva J, Bhorade SM, Robinson JA, Husain AN, Garrity ER Jr: Extracorporeal photopheresis for the treatment of lung allograft rejection. Ann Transplant 2000;5:44-47.

43 Urbani L, Mazzoni A, Catalano G, De Simone P, Vanacore R, Pardi C, Bortoli M, Biancofiore G, Campani D, Perrone V, Mosca F, Scatena F, Filipponi F: The use of extracorporeal photopheresis for allograft rejection in liver transplant recipients. Transplant Proc 2004;36:3068-3070.
44 Urbani L, Mazzoni A, Colombatto P, Biancofiore G, Bindi L, Tascini C, Menichetti F, Brunetto M, Scatena F, Filipponi F: Potential applications of extracorporeal photopheresis in liver transplantation. Transplant Proc 2008;40:1175-1178.

45 Genberg H, Kumlien G, Shanwell A, Tyden G: Refractory acute renal allograft rejection successfully treated with photopheresis. Transplant Proc 2005; 37:3288-3289.

-46 Knobler R, Barr ML, Couriel DR, Ferrara JL, French LE, Jaksch P, Reinisch W, Rook AH, Schwarz T, Greinix H: Extracorporeal photopheresis: past, present, and future. J Am Acad Dermatol 2009;61:652-665.

47 Jardine MJ, Bhandari S, Wyburn KR, Misra AK, McKenzie PR, Eris JM: Photopheresis therapy for problematic renal allograft rejection. J Clin Apher 2009;24:161-169.

48 Reinisch W, Nahavandi H, Santella R, Zhang Y, Gasche C, Moser G, Waldhor T, Gangl A, Vogelsang H, Knobler R: Extracorporeal photochemotherapy in patients with steroid-dependent Crohn's disease: a prospective pilot study. Aliment Pharmacol Ther 2001;15:1313-1322.

49 Reinisch W, Knobler R, Rutgeerts PJ, Ochsenkuhn T, Anderson F, von Tirpitz C, Kaatz M, van der Woude CJ, Parenti D, Mannon PJ: Extracorporea photopheresis (ECP) in patients with steroid-dependent Crohn's disease: an open-label, multicenter, prospective trial. Inflamm Bowel Dis 2012; doi: 10.1002/ibd.23012.

50 Abreu MT, von Tirpitz C, Hardi R, Kaatz M, Van Assche G, Rutgeerts P, Bisaccia E, Goerdt S, Hanauer S, Knobler R, Mannon P, Mayer L, Ochsenkuhn T, Sandborn WJ, Parenti D, Lee K, Reinisch W: Extracorporeal photopheresis for the treatment of refractory Crohn's disease: results of an open-label pilot study. Inflamm Bowel Dis 2009; 15:829-836.

51 Szczepiorkowski ZM, Winters JL, Bandarenko N, Kim HC, Linenberger ML, Marques MB, Sarode R, Schwartz J, Weinstein R, Shaz BH: Guidelines on the use of therapeutic apheresis in clinical practice - evidence-based approach from the Apheresis Applications Committee of the American Society for Apheresis. J Clin Apher2010;25: 83-177.

52 Heald PW, Perez MI, Christensen I, Dobbs N, McKiernan G, Edelson R: Photopheresis therapy of cutaneous T-cell lymphoma: the Yale-New Haven Hospital experience. Yale J Biol Med 1989; 62:629-638

53 Zic J, Arzubiaga C, Salhany KE, Parker RA, Wilson D, Stricklin GP, Greer J, King LE Jr: Extracorporeal photopheresis for the treatment of cutaneous T-cell lymphoma. J Am Acad Dermatol 1992;27:729-736.

54 Prinz B, Behrens W, Holzle E, Plewig G: Extracorporeal photopheresis for the treatment of cutaneous T-cell lymphoma - the Dusseldorf and Munich experience. Arch Dermatol Res 1995;287:621-626.

55 Gottlieb SL, Wolfe JT, Fox FE, DeNardo BJ, Macey WH, Bromley PG, Lessin SR, Rook AH: Treatment of cutaneous T-cell lymphoma with extracorporeal photopheresis monotherapy and in combination with recombinant interferon alfa: a 10-year experience at a single institution. J Am Acad Dermatol 1996;35:946-957.

56 Duvic M, Hester JP, Lemak NA: Photopheresis therapy for cutaneous T-cell lymphoma. J Am Acad Dermatol 1996;35:573-579.

57 Vonderheid EC, Zhang Q, Lessin SR, Polansky M, Abrams JT, Bigler RD, Wasik MA: Use of serum soluble interleukin-2 receptor levels to monitor the progression of cutaneous T-cell lymphoma. J Am Acad Dermatol 1998;38:207-220. 
-58 Zouboulis CC, Schmuth M, Doepfmer S, Dippel E, Orfanos CE: Extracorporeal photopheresis of cutaneous T-cell lymphoma is associated with reduction of peripheral CD4+ T lymphocytes. Dermatology 1998;196:305-308.

-59 Jiang SB, Dietz SB, Kim M, Lim HW: Extracorporeal photochemotherapy for cutaneous T-cell lymphoma: a 9.7-year experience. Photodermatol Photoimmunol Photomed 1999;15:161-165.

60 Bisaccia E, Gonzalez J, Palangio M, Schwartz J, Klainer AS: Extracorporeal photochemotherapy alone or with adjuvant therapy in the treatment of cutaneous T-cell lymphoma: a 9-year retrospective study at a single institution. J Am Acad Dermatol 2000;43:263-271.

61 Crovetti G, Carabelli A, Berti E, Guizzardi M, Fossati S, De Filippo C, Bertani E: Photopheresis in cutaneous T-cell lymphoma: five-year experience. Int J Artif Organs 2000;23:55-62.

62 Wollina U, Liebold K, Kaatz M, Looks A, Stuhlert A, Lange D: Survival of patients with cutaneous Tcell lymphoma after treatment with extracorporeal photochemotherapy. Oncol Rep 2000;7:1197-1201.

63 Bouwhuis SA, el-Azhary RA, McEvoy MT, Gibson LE, Habermann TM, Witzig TE, Pittelkow MR: Treatment of late-stage Sezary syndrome with 2-chlorodeoxyadenosine. Int J Dermatol 2002;41: 352-356.

64 Knobler E, Warmuth I, Cocco C, Miller B, Mackay J: Extracorporeal photochemotherapy - the Columbia Presbyterian experience. Photodermatol Photoimmunol Photomed 2002;18:232-237.

-65 Suchin KR, Cucchiara AJ, Gottleib SL, Wolfe JT, DeNardo BJ, Macey WH, Bromley PG, Vittorio CC, Rook AH: Treatment of cutaneous T-cell lymphoma with combined immunomodulatory therapy: a 14-year experience at a single institution. Arch Dermatol 2002;138:1054-1060.

-66 Quaglino P, Fierro MT, Rossotto GL, Savoia P, Bernengo MG: Treatment of advanced mycosis fungoides/Sezary syndrome with fludarabine and potential adjunctive benefit to subsequent extracorporeal photochemotherapy. $\mathrm{Br} \mathrm{J}$ Dermato 2004;150:327-336.
67 Richardson SK, Lin JH, Vittorio CC, Kim EJ, Yoon JS, Junkins-Hopkins J, Rook AH: High clinical response rate with multimodality immunomodulatory therapy for Sezary syndrome. Clin Lymphoma Myeloma 2006;7:226-232.

68 Salvaneschi L, Perotti C, Zecca M, Bernuzzi S, Viarengo G, Giorgiani G, Del Fante C, Bergamaschi P, Maccario R, Pession A, Locatelli F: Extracorporeal photochemotherapy for treatment of acute and chronic GVHD in childhood. Transfusion 2001;41:1299-1305.

69 Dall'Amico R, Messina C: Extracorporeal photochemotherapy for the treatment of graft-versushost disease. Ther Apher 2002;6:296-304.

70 Garban F, Drillat P, Makowski C, Jacob MC, Richard MJ, Favrot M, Sotto JJ, Bensa JC, Cahn JY: Extracorporeal chemophototherapy for the treatment of graft-versus-host disease: hematologic consequences of short-term, intensive courses. Haematologica 2005;90:1096-1101.

71 Kanold J, Merlin E, Halle P, Paillard C, Marabelle A, Rapatel C, Evrard B, Berger C, Stephan JL, Galambrun C, Piguet C, D'Incan M, Bordigoni P, Demeocq F: Photopheresis in pediatric graft-versus-host disease after allogeneic marrow transplantation: clinical practice guidelines based on field experience and review of the literature. Transfusion 2007; 47:2276-2289.

72 Perfetti P, Carlier P, Strada P, Gualandi F, Occhini D, Van Lint MT, Ibatici A, Lamparelli T, Bruno B, Raiola AM, Dominietto A, Di Grazia C, Bregante S, Zia S, Ferrari GM, Stura P, Pogliani E, Bacigalupo A: Extracorporeal photopheresis for the treatment of steroid refractory acute GVHD. Bone Marrow Transplant 2008;42:609-617.

73 Calore E, Calo A, Tridello G, Cesaro S, Pillon M, Varotto S, Gazzola MV, Destro R, Marson P, Trentin L, Carli M, Messina C: Extracorporeal photochemotherapy may improve outcome in children with acute GVHD. Bone Marrow Transplant 2008;42:421-425.

74 Perotti C, Del Fante C, Tinelli C, Viarengo G, Scudeller L, Zecca M, Locatelli F, Salvaneschi L: Extracorporeal photochemotherapy in graft-versus-host disease: a longitudinal study on factors influencing the response and survival in pediatric patients. Transfusion 2010;50:1359-1369.
75 Smith EP, Sniecinski I, Dagis AC, Parker PM, Snyder DS, Stein AS, Nademanee A, O'Donnell MR, Molina A, Schmidt GM, Stepan DE, Kapoor N Niland JC, Forman SJ: Extracorporeal photochemotherapy for treatment of drug-resistant graft-vs. host disease. Biol Blood Marrow Transplant 1998; 4:27-37.

76 Seaton ED, Szydlo RM, Kanfer E, Apperley JF, Russell-Jones R: Influence of extracorporeal photopheresis on clinical and laboratory parameters in chronic graft-versus-host disease and analysis of predictors of response. Blood 2003;102:1217-1223.

77 Apisarnthanarax N, Donato M, Korbling M, Couriel D, Gajewski J, Giralt S, Khouri I, Hosing C, Champlin R, Duvic M, Anderlini P: Extracorporeal photopheresis therapy in the management of steroid-refractory or steroid-dependent cutaneous chronic graft-versus-host disease after allogeneic stem cell transplantation: feasibility and results. Bone Marrow Transplant 2003;31:459-465.

78 Foss FM, DiVenuti GM, Chin K, Sprague K, Grodman H, Klein A, Chan G, Stiffler K, Miller KB: Prospective study of extracorporeal photopheresis in steroid-refractory or steroid-resistant extensive chronic graft-versus-host disease: analysis of response and survival incorporating prognostic factors. Bone Marrow Transplant 2005;35:1187-1193.

79 Rubegni P, Cuccia A, Sbano P, Cevenini G, Carcagni MR, D'Ascenzo G, De Aloe G, Guidi S, Guglielmelli P, Marotta G, Lauria F, Bosi A, Fimiani M: Role of extracorporeal photochemotherapy in patients with refractory chronic graft-versus-host disease. Br J Haematol 2005;130:271-275.

80 Perseghin P, Galimberti S, Balduzzi A, Bonanomi S, Baldini V, Rovelli A, Dassi M, Rambaldi A, Castagna L, Corti P, Pogliani EM, Uderzo C: Extracorporeal photochemotherapy for the treatment of chronic graft-versus-host disease: trend for a possible cell dose-related effect? Ther Apher Dial 2007;11:85-93. 